Jenius: Jurnal of Education Policy and Elementary Education Issues

Vol.1, No.2, Desember 2020, pp. 83-89

\title{
PENINGKATAN KOMPETENSI GURU MENYUSUN RENCANA PELAKSANAAN PEMBELAJARAN (RPP) MELALUI WORKSHOP
}

\author{
Parlan \\ SDN 2 Kutoharjo, Kec. Rembang, Kab. Rembang \\ E-mail: parlan7272@gmail.com
}

\begin{abstract}
The quality of a teacher's work can be described by his competence in teaching. References used by teachers in teaching must be designed in a draft teaching implementation plan (RPP). However, not all teachers have competence in designing lesson plans, so that teaching is not in accordance with learning outcomes and learning is less effective, this has an impact on the competencies that each student must possess. The purpose of this study was to improve teacher competence in designing lesson plans through a workshop at SDN 2 Kutoharjo. This type of research is School Action Research (PTS). The sampling technique used was purposive sampling, namely teachers who had less competence in designing lesson plans, consisting of 9 classroom teachers. The time of this research is three months, from October to December. The source of research data is the RPP document. The technique of collecting research data is non-test with observation and documentation. The research data analysis technique is comparative descriptive. The results of this study are the competence of Class Teachers in preparing lesson plans through workshops at SDN 2 Kutoharjo Semester I for the 2019/2020 academic year increased from the Enough category (C) to the Very Good category (A).
\end{abstract}

Keywords: Competence; Learning Implementation Plan (RPP); Workshop

Abstrak Kualitas kerja guru dapat tergambarkan dari kompetensinya dalam mengajar. Acuan yang digunakan guru dalam mengajar harus di rancang dalam suatu rancangan rencana pelaksanaan mengajar (RPP). Namun, belum semua guru memiliki kompetensi dalam merancang RPP, sehingga dalam mengajarnya kurang sesuai dengan capaian pembelajaran dan pembelajarannya pun kurang efektif, hal ini berdampak pada kompetensi yang harus dimiliki setiap peserta didik. Tujuan penelitian ini adalah meningkatkan kompetensi guru dalam merancang RPP melalui workshop di SDN 2 Kutoharjo. Jenis penelitian ini adalah Penelitian Tindakan Sekolah (PTS). Teknik pengambilan sampel menggunakan purposive sampling, yaitu guru yang memiliki kompetensi yang kurang dalam merancang RPP, terdiri dari 9 orang Guru Kelas. Waktu penelitian ini tiga bulan, yaitu bulan Oktober sampai bulan Desember. Sumber data penelitian adalah dokumen RPP. Teknik pengumpulan data penelitian adalah non tes dengan observasi dan dokumentasi. Teknik analisis data penelitian adalah deskriptif komparatif. Hasil penelitian ini adalah kompetensi Guru Kelas menyusun RPP melalui workshop di SDN 2 Kutoharjo Semester I Tahun Pelajaran 2019/2020 meningkat dari kategori Cukup (C) menjadi kategori Amat Baik (A).

Kata Kunci : Kompetensi; Rencana Pelaksanaan Pembelajaran (RPP); Workshop 


\section{PENDAHULUAN}

Kompetensi guru di Indonesia merupakan suatu hal yang menarik, pasalnya kompetensi guru menjadi pekerjaan rumah yang harus ditingkatkan karena guru yang kompeten merupakan kunci dari pendidikan yang efektif. Guru diharuskan memiliki kompetensi yang pedagogik, professional, kepribadian dan sosial (UU No 14 Tahun 2005 tentang guru dan dosen). Namun, berdasarkan uji kompetensi guru (UKG) dengan nilai standart kelulusan 80, terdapat sekitar 41.000 guru yang tidak lulus, sehingga dilakukan UKG ulang dengan menurunkan nilai standart kelulusan menjadi 65 (Detiknews, 2017). hal ini membuktikan masih rendahnya kompetensi guru di Indonesia.

Rendahnya kompetensi guru ini salah satunya disebabkan kurangnya pengembangan diri guru dengan semakin berkembangnya ilmu pengetahuan dan teknologi (Nuryani \& Handayani, 2020). Berdasarkan penelitian Sobegjo (2020) kopetensi pedagogik guru dalam menyusun RPP masih kurang, hal ini disebabkan karena guru belum memahami koponen dan prinsip dalam penyusunan RPP. Berdasar hasil observasi dan dokumentasi di SDN 2 Kutoharjo, sebagian besar guru yang memiliki kemampuan rendah dalam menyusun RPP. Keadaan ini ditunjukkan sebagian besar RPP yang dihasilkan adalah RPP fotocopi, RPP yang digunakan adalah RPP Tahun Pelajaran sebelumnya atau RPP yang dibuat oleh guru lain yang dikerjakan bersama dalam forum KKG dalam gugus sekolah. Hal ini menandakan bahwa guru belum menyusun RPP secara mandiri. Dari hasil supervisi akademik terhadap guru di SDN 2 Kutoharjo pada Semester I Tahun Pelajaran 2019/2020, dari 9 Guru Kelas berdasar instrumen penilaian yang disusun sekolah yang memuat unsur kelengkapan RPP, nilai rata-rata dalam menyusun RPP adalah 72,5 yang termasuk kategori Cukup (C). Dari data tersebut, ada 4 guru atau 44\% dinyatakan dengan kategori Kurang (D). Sisanya, sebanyak 5 guru atau 66\% dengan kategori Cukup (C). Dilihat dari proses penyusunannya, sebagian besar guru masih menggunakan RPP Tahun Pelajaran sebelumnya dan belum ada perubahan. Sebagian lagi menggunakan RPP fotocopi, kemudian menyesuaikan tanggal pelaksanaan. Hal ini menjadi masalah bagi guru karena RPP seharusnya selalu berubah sesuai dengan kekinian. Padahal seluruh kelas, dari Kelas I sampai Kelas VI, pada Tahun Pelajaran 2019/2020 sudah menggunakan Kurikulum 2013 (Kurtilas).

Menurut Mulyasa (2007: 102), RPP merupakan pedoman untuk melaksanakan pembelajaran. Demikian pula menurut Bestary (2018: 79), salah satu faktor penentu keberhasilan pembelajaran adalah kemampuan guru dalam menyusun perencanaan yang tertuang dalam RPP. Hal ini berarti bahwa RPP yang disusun guru dapat membawa dampak pada keberhasilan dan prestasi peserta 
Jenius: Jurnal of Education Policy and Elementary Education Issues

Vol.1, No.2, Desember 2020, pp. 83-89

didik, sehingga indikasi kemampuan guru dalam merancang pembelajaran akan terlihat dalam penyusunan RPP tersebut. Lebih lanjut berarti bahwa kemampuan guru merancang pembelajaran dan menyusun RPP sesuai dengan kompetensinya, yaitu kompetensi pedagogik yang berkaitan dengan perencanaan pengajaran. Mengingat kompetensi Guru Kelas SDN 2 Kutoharjo dalam menyusun RPP masih termasuk kategori Cukup (C), maka perlu ditingkatkan.

Berdasarkan uraian tersebut, maka perlu dilakukan Penelitian Tindakan Sekolah. Tindakan tersebut adalah melalui Workshop penyusunan RPP bagi guru-guru. Menurut Azhari (2014) salah satu usaha untuk meningkatkan kompetensi guru adalah dengan membina guru melalui kegiatan workshop. Sahertian dan Mataheru (1981: 108) menjelasan workshop di bidang pendidikan adalah suatu kegiatan yang dilakukan untuk mengembangkan kesanggupan berpikir dan bekerja bersama-sama secara kelompok maupun individual untuk membahas dan memecahkan segala permasalahan yang ada, baik mengenai masalah-masalah yang bersifat teoritis maupun yang bersifat praktis dengan tujuan untuk meningkatkan kualitas kompetensi pedagogik dan kepribadian guru, sehingga dapat menjalankannya sesuai dengan tugas masing-masing. Hasil penelitian Sukoyo (2013) dan Zukmadini, Karyadi \& Rochman (2021) menjelaskan bahwa melalui workshop, kompetensi guru dapat meningkat. Hal ini sejalan dengan penelitian Affandi dkk (2018) bahwasanya kegiatan workshop dapat meningkatkan kemampuan guru dalam menyusun RPP. Workshop membahas dengan tuntas permasalahan tertentu dengan adanya pemberian pelatihan atau materi khusus kepada para peserta, sehingga mendapatkan ilmu, pengetahuan, keterampilan serta wawasan yang baru untuk kemudian diterapkan sesuai perkembangan zaman. Berdasarkan

permasalahan kompetensi guru dalam merancang RPP di SDN 2 Kutoharjo, maka peneliti tertarik untuk menerapkan kegiatan workshop dalam melatih keterampilan guru merancang RP melalui tindakan sekolah sebagai upaya kepala sekolah mendorong kinerja dan potensi guru untuk meningkatkan kompetensinya.

\section{METODE}

Jenis penelitian ini merupakan Penelitian Tindakan Sekolah (PTS). Tindakan yang dilakukan melalui workshop untuk meningkatkan kompetensi guru dalam menyususn RPP. Subjek penelitian ini adalah Guru Kelas SDN 2 Kutoharjo, Kecamatan Rembang, Kabupaten Rembang yang terdiri atas 9 orang, yaitu Guru Kelas IA, IB, IIA, IIB, III, IV, VA, VB dan VI. Teknik pengambilan sampel yaitu purposive sampling, dimana pemilihan subyek berdasarkan hasil supervisi guru dalam merancang RPP masih kurang terampil. Subjek penelitian terdiri dari 4 guru 
Jenius: Jurnal of Education Policy and Elementary Education Issues

Vol.1, No.2, Desember 2020, pp. 83-89

laki-laki dan 5 guru perempuan. Waktu penelitian ini pada Semester I Tahun Pelajaran 2019/2020, tepatnya selama tiga bulan, yaitu bulan Oktober sampai bulan Desember. Penelitian berlangsung selama dua siklus. Tindakan pada Siklus I adalah workshop dengan penugasan secara individual. Tindakan pada Siklus II adalah workshop dengan penugasan secara kelompok. Sumber data penelitian adalah dokumen RPP. Teknik pengumpulan data penelitian adalah non tes dengan observasi dan dokumentasi. Teknik analisis data penelitian adalah deskriptif komparatif. Aspek penilaian RPP meliputi:

Tabel 1. Aspek penilaian Rencana Pelaksanaan Pembelajaran

\begin{tabular}{|c|c|c|}
\hline No & Aspek & Indikator \\
\hline 1 & Tujuan pembelajaran & $\begin{array}{l}\text { Kesesuaian tujuan dengan indicator kompetensi } \\
\text { Kata kerja operasinal yang digunakan dapat diukur } \\
\text { Tujuan pembelajaran (mencakup: aspek kognitif, psikomotor, } \\
\text { afektif) } \\
\text { Perumusan tujuan pembelajaran }\end{array}$ \\
\hline 2 & Materi pembelajaran & $\begin{array}{l}\text { Kesesuaian materi pembelajaran dengan kompetensi dasar } \\
\text { dan indikator yang akan dicapai } \\
\text { Susunan materi pembelajaran } \\
\text { Bahan ajar }\end{array}$ \\
\hline 3 & Strategi pembelajaran & $\begin{array}{l}\text { Model, pendekatan, dan metode pembelajaran } \\
\text { Langkah-langkah/sintaks pembelajaran } \\
\text { Tahapan kegiatan pembelajaran } \\
\text { Penerapan active learning }\end{array}$ \\
\hline 4 & $\begin{array}{l}\text { Pemilihan } \\
\text { Pembelajaran }\end{array}$ & $\begin{array}{l}\text { Sesuai dengan tujuan pembelajaran, materi pembelajaran, } \\
\text { kondisi kelas, dan memperhatikan keselamatan }\end{array}$ \\
\hline 5 & Pemilihan Sumber Belajar & $\begin{array}{l}\text { Cetak maupun elektronik dan memperhatikan relevansi dan } \\
\text { kemutakhiran }\end{array}$ \\
\hline 6 & Evaluasi & Mencakup: aspek kognitif, psikomotor dan afektif \\
\hline
\end{tabular}

Tabel 2. Kategori penilaian Kompetensi guru dalam menyusun RPP

\begin{tabular}{lll}
\hline No & Kategori & Interval \\
\hline 1 & A (Amat baik) & $90-100$ \\
2 & B (Baik) & $80-90$ \\
3 & C (Cukup) & $70-80$ \\
4 & D (Kurang) & $\leq 70$ \\
\hline
\end{tabular}

(Sumber: Subegjo, 2020)

\section{HASIL DAN PEMBAHASAN}

Isman (2011) menjelaskan bahwasanya perencanaan pembelajaran berfungsi sebagai acuan proses pembelajaran, sedangkan Reiser \& Dempse (2007) dalam Sell, Lehman, Blumschein \& 
Jenius: Jurnal of Education Policy and Elementary Education Issues

Vol.1, No.2, Desember 2020, pp. 83-89

Podolskiy (2017) menjelaskan perencanaan pembelajaran merupakan prosedur yang sistematis yang dikembangkan untuk tujuan peningkatan pembelajaran yang subtansial. Sehingga kompetensi guru dalam menyusun perencanaan pembelajaran merupakan salah satu hal yang krusial untuk dikuasai guru.

Berdasarkan hasil analisis kompetensi guru dalam menyusun RPP dalam grafik dan tabel sebagai berikut:

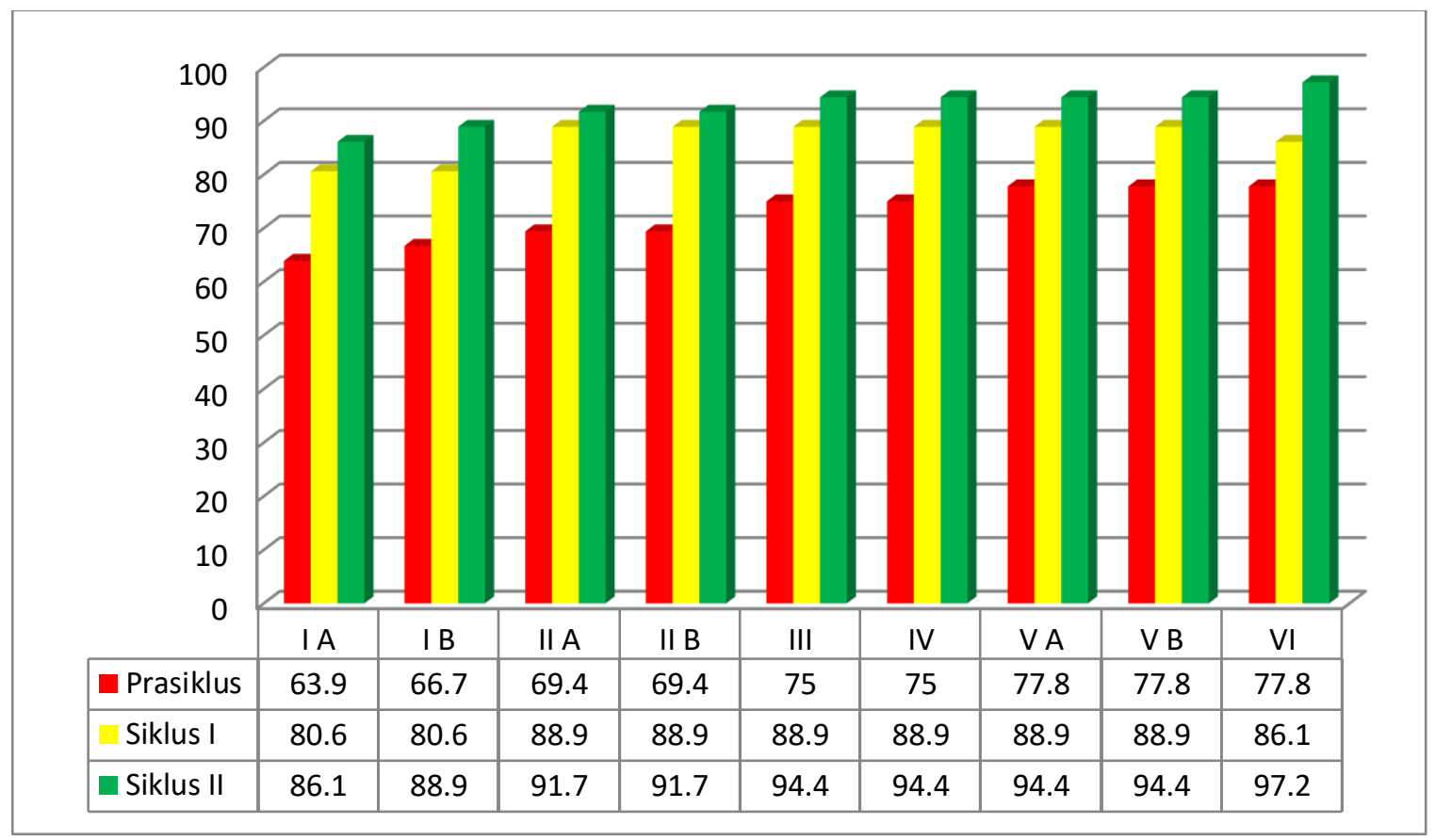

Gambar 1. Analisis kompetensi guru dalam menyusun RPP pada Prasiklus, Siklus I dan Siklus II.

Sebelum dilakukannya tindakan melalui workshop untuk meningkatkan kompetensi guru dalam merancang RPP, dilakukan pra siklus terlebih dahulu untuk mengetahui sejauh mana kemampuan guru dalam merancang RPP. Pada Prasiklus, kompetensi guru menyusun RPP dengan nilai rata-rata sebesar 72,5 yang termasuk kategori Cukup (C). Rinciannya adalah 4 guru atau 44\% dengan kategori Kurang (D) dan 5 guru atau 66\% dengan kategori Cukup (C). Kompetensi guru termasuk kategori Cukup (C). Rendahnya nilai rata-rata guru dalam merancang RPP disebabkan karena sebagian besar guru masih belum bisa merumuskan tujuan pembelajaran, tujuan pembelajaran masih belum sesuai dengan indikator kompetensi, dan kalimat yang digunakan masih belum menggunakan kata operasional. Guru juga masih belum dapat menguasai materi dengan baik dan sumber belajar yang digunakan masih kurang tepat, dimana guru mengabaikan tujuan belajar maupun sumber, alat dan bahan yang sangat berkaitan dengan materi. Selaian itu 
strategi yang digunakan juga masih belum sesaui dengan materi yang diajarkan, dimana setiap langkah dalam model pembelajaran tidak dijabarkan secara jelas. Sanjaya (2008) dan Zendrato (2016) menjelaskan proses pembelajaran tergantung dari tujuan pembelajaran, materi dan karakeristik siswa. Sehingga apabila guru tidak dapat merumuskan tujuan pembelajaran yng tepat, penguasaan materi dan tidak dapat mengenali lingkungan belajar peserta didik, maka akan berdampak pada keefektifan proses pembelajaran di kelas.

Pada Siklus I, workshop dilakukan dengan menyampaikan materi tentang urgensi RPP dan langkah dalam menyusun RPP dengan baik dan benar, setelah materi semua diberikan, guru diminta untuk merancang RPP sesuai dengan materi yang telah dijelaskan. Sesuai dengan tindakan tersebut, kompetensi guru menyusun RPP dievaluasi dan didapatkan nilai rata-rata sebesar 86,1 yang termasuk kategori Baik (B). Rinciannya adalah 7 guru atau 77\% dengan kategori Baik (B) dan 2 guru atau 23\% dengan kategori Cukup (C). Namun, persentase guru dengan kompetensi yang termasuk kategori Baik (B) sebesar 77\% dan belum secara keseluruhan meningkat, dimana masih terdapat guru yang masih kurang terampil dalam merancang RPP. Dengan demikian, peningkatan kompetensi guru belum optimal dan penelitian dilanjutkan pada Siklus II dengan pembaruan tindakan.

Sesuai dengan refleksi pada Siklus I, workshop cukup berhasil meningkatkan kompetensi guru dalam menyusun RPP. Kompetensi guru menyusun RPP dengan nilai rata-rata yang semakin meningkat, yaitu kategori Cukup (C) menjadi kategori Baik (B). Oleh karena itu, penelitian dilanjutkan dan tindakan diperbarui pada Siklus II. Tindakan tersebut adalah workshop dalam kelompok. Subjek penelitian dikelompokkan berdasarkan tugas sebagai guru kelas, yaitu guru kelas rendah dan guru kelas tinggi. Pada Siklus II, workshop dilakukan dengan memberikan materi dan konsultasi serta saling mengoreksi RPP yang dirancang guru.

Subjek penelitian dibagi menjadi dua kelompok, yaitu guru kelas rendah yang terdiri dari guru kelas IA, IB, IIA, IIB dan III (lima anggota) dan guru kelas tinggi yang terdiri dari guru kelas IV, VA, VB dan VI (empat anggota). Sesuai dengan tindakan tersebut, kompetensi guru menyusun RPP dengan nilai rata-rata sebesar 91,7 yang termasuk kategori Amat Baik (A). Rinciannya adalah 7 guru atau 77\% dengan kategori Amat Baik (A) dan 2 guru atau 23\% dengan kategori Baik (B). Seluruh guru dengan kompetensi yang termasuk kategori Baik (B) dan Amat Baik (A). Secara keseluruhan, kompetensi guru termasuk kategori Amat Baik (A) karena rancangan RPP terlebih dahulu ditelaah bersama dalam kelompok, dikoreksi, kemudian penilaian akhir. Dengan demikian, peningkatan kompetensi guru benar-benar optimal dan penelitian dihentikan pada Siklus II. 
Jenius: Jurnal of Education Policy and Elementary Education Issues

Vol.1, No.2, Desember 2020, pp. 83-89

Meningkatnya kompetensi guru dalam merangcang RPP sejalan dengan penelitian Affandi dkk (2018) bahwasanya melalui workshop memberikan kesempatan untuk melakukan kolaborasi antar guru, selain itu workshop dilakukan melalui pendampingan dalam membantu guru menyusun RPP dan memastikan kinerja guru dalam menyususn RPP sudah baik dan benar. Seel, Lehmann, Blumschein, \& Podolskiy (2017) menjelaskan bahwa RPP merupakan acuan untuk memudahkan guru melakukan proses pembelajaran, sehingga tujuan pembelajaran dapat tercapai.

\section{KESIMPULAN DAN SARAN}

\section{Simpulan}

Pada Prasiklus, kompetensi guru menyusun RPP dengan nilai rata-rata sebesar 72,5 yang termasuk kategori Cukup (C). RPP merupakan perencanaan KBM yang terstruktur dan menjadi acuan bagi guru. Setelah dilakukannya workshop dalam penyusunan RPP, kompetensi guru menyusun RPP meningkat secara optimal dari kategori Cukup (C) menjadi kategori Amat Baik (A). Peningkatan tersebut karena dalam kegiatan workshop memberikan kesempatan guru untuk mendapatkan penjelasan yang benar dalam menyusun RPP, melakukan kolaborasi dengan sesama guru dalam bidang yang sama dan pendampingan dalam menyusun RPP.

\section{DAFTAR PUSTAKA}

Affandi, L. H., Ermiana, I., Khairunnisa, K., Witono, H., \& Widiada, I. K. (2018). Workshop penyusunan rencana pembelajaran inovatif berbasis lesson study bagi guru SDN 12 Ampenan. Jurnal Pendidikan dan Pengabdian Masyarakat, 1(1).

Azhari. (2014). Upaya kepala madrasah dalam membina kompetensi Profesional Guru pada MAN Peusangan. Theses. Banda Aceh: Universitas Syiah Kuala. Retrieved from http:/ /etd.unsyiah.ac.id/index.php?p=show_detail\&id=7281

Bestary, R. (2018). Modul manajemen implementasi kurikulum 2013, jenjang SD. Jakarta: Dirjen GTK, Kementerian Pendidikan dan Kebudayaan.

Detik news. (2017). Mengkritisi kompetensi guru. Retrieved from: https:/ / news.detik.com/kolom/d3741162/mengkritisi-kompetensi-guru,

Haryanti, P. (2019). Upaya kepala sekolah dalam membina kompetensi profesional guru di SMK Ma'arifNU Limpung Kabupaten Batang (Doctoral dissertation, IAIN Pekalongan).

Isman, A. (2011). Instructional design in education: New model. Turkish Online Journal of Educational Technology - TOJET, 10(1), 136-142.

Mulyasa, E. (2007). Standar kompetensi dan sertifikasi guru. Bandung: Remaja Rosdakarya.

Nuryani, D., Handayani, I. 2020. Kompetensi guru di era 4.0 dalam meningkatkan mutu pendidikan. prosiding seminar nasional pendidikan program pascasarjana universitas PGRI Palembang.

Sahertian, P. dan Mataheru, F. (1981). Prinsip dan teknik supervisi pendidikan. Surabaya: Usaha 
Nasional.

Sanjaya, W. (2008). Kurikulum dan pembelajaran teori dan praktik pengembangan kurikulum tingkat satuan pendidikan (KTSP). Jakarta: Kencana

Seel, N. M., Lehmann, T., Blumschein, P., \& Podolskiy, O. A. (2017). What is Instructional Design? Instructional Design for Learning, 1-17. https:/ / doi.org/10.1007/978-94-6300-941-6_1

Subegjo, E. (2020). Peningkatan kompetensi guru menyusun rencana pelaksanaan pembelajaran integratif. Dinamika Pendidikan, $10(3)$.

Sukoyo, J. (2013). Peningkatan kompetensi guru melalui workshop penyusunan soal digital bahasa jawa dengan menggunakan program adobe captivate. Rekayasa: Jurnal Penerapan Teknologi dan Pembelajaran, 11(2), 133-138.

Zendrato, J. (2016). Tingkat penerapan rencana pelaksanaan pembelajaran dalam pelaksanaan pembelajaran di kelas suatu studi kasus di SMA Dian Harapan Jakarta. Scholaria: Jurnal Pendidikan Dan Kebudayaan, 6(2), 58-73.

Zukmadini, A. Y., Karyadi, B., \& Rochman, S. (2021). Peningkatan kompetensi guru melalui workshop model integrasi terpadu literasi sains dan pendidikan karakter dalam pembelajaran IPA. Publikasi Pendidikan, 11(2), 107-116. 